\title{
Peranan BUMN dalam Pelaksanaan Tanggung Jawab Sosial Perusahaan untuk Meningkatkan Kesejahteraan Rakyat
}

\author{
Yeti Sumiyati \\ Fakultas Hukum Universitas Islam Bandung \\ Jl. Rangga Gading No. 8 Bandung \\ yeti_sumiyati74@yahoo.com
}

\begin{abstract}
The problems studied in this research are: First, the role of State-Owned Enterprises (SOEs) in producing high quality goods/service through the SOE management and control based on the GCG principles; second, the role of SOEs in promoting the small scale industries/cooperatives development through Corporate Social Responsibility (CSR). The method used in this research is normative juridical. This research finds and concludes that: First, in any aspects, the implementation of SOE roles is still far from ideal as stipulated in the Article 33 of Constitution 1945, which should be beneficial for the prosperity and welfare of the community. In fact, the SOEs have already implemented the GCG principles in their management and control as the effort to optimize the role of SOEs. Second, the role of SOEs to promote the development of the farmers' small scale industries/cooperatives through the implementation of CSR can at least help create the independence economic of the farmers as long as the implementation is sustainable and involve the participation of all farmer community.
\end{abstract}

Key words: Role of SOEs, good corporate governance, corporate social responsibility, promoting the people welfare

\begin{abstract}
Abstrak
Penelitian ini mengkaji permasalahan: pertama, peranan BUMN dalam menghasilkan barang dan/ atau jasa yang bermutu tinggi melalui pengurusan dan pengawasan BUMN berdasarkan prinsipprinsip GCG. Kedua, peranan BUMN untuk turut membantu pengembangan usaha kecil/koperasi melalui pelaksanaan tanggung jawab sosial perusahaan. Metode yang digunakan dalam penelitian ini adalah yuridis normatif. Hasil penelitian ini menyimpulkan: pertama, dalam berbagai aspek, peranan BUMN belum terlaksana secara ideal seperti apa yang diamanatkan Pasal 33 UUD 1945, yang peruntukannya sebesar-besarnya untuk kemakmuran dan kesejahteraan rakyat padahal, BUMN telah menerapkan prinsip-prinsip GCG dalam pengurusan dan pengawasannya sebagai upaya untuk mengoptimalkan peranan BUMN. Kedua, peranan BUMN untuk turut membantu pengembangan usaha kecil/koperasi petani melalui pelaksanaan tanggung jawab sosial paling tidak dapat mendorong kemandirian ekonomi petani dengan syarat pelaksanaannya berjalan secara berkesinambungan dan melibatkan partisipasi masyarakat petani.
\end{abstract}

Kata kunci :Peranan BUMN, tata kelola perusahaan yang baik, tanggung jawab sosial perusahaan, peningkatan kesejahteraan rakyat. 


\section{Pendahuluan}

Badan Usaha Milik Negara (BUMN) adalah badan usaha yang dimiliki oleh negara dan dikelola oleh pemerintah. Keberadaan BUMN merupakan konsekuensi dari faham negara kesejahteraan yang dianut Indonesia. Karakteristik negara kesejahteraan adalah keikutsertaan pemerintah dalam seluruh sektor kehidupan masyarakat termasuk sektor perekonomian masyarakat.

Penjelasan Undang-Undang Nomor 19 Tahun 2003 tentang Badan Usaha Milik Negara $^{1}$ menyatakan, bahwa memajukan kesejahteraan bagi seluruh rakyat sebagaimana diamanatkan dalam Pembukaan Undang-Undang Dasar (UUD) 1945 dan Pasal 33 UUD 1945 merupakan tugas konstitusional bagi seluruh komponen bangsa termasuk di dalamnya BUMN. Melalui kepemilikan negara terhadap unitunit usaha tertentu, peran BUMN dalam menghasilkan barang dan/atau jasa yang bermutu tinggi dengan harga yang terjangkau serta mampu berkompetisi dalam persaingan bisnis secara global, diharapkan dapat memberikan manfaat yang sebesar-besarnya bagi kemakmuran rakyat dan meningkatkan kesejahteraan rakyat. ${ }^{2}$

Menumbuhkan budaya korporasi dan profesionalisme melalui antara lain pembenahan pengurusan dan pengawasan berdasarkan prinsip-prinsip Good Corporate Governance (GCG) menjadi syarat mutlak bagi optimalnya peran BUMN. Restrukturisasi dan privatisasi menjadi upaya yang penting dilakukan dalam peningkatan efisiensi dan produktivitas BUMN.

Tanggung jawab sosial perusahaan sebagai salah satu peran BUMN untuk turut membantu pengembangan usaha kecil/koperasi, menjadi hal yang krusial dilakukan seiring dengan tuntutan dan kesadaran masyarakat akan pentingnya kualitas hidup yang ideal. Kontribusi BUMN terhadap terciptanya ketangguhan dan kemandirian ekonomi rakyat melalui upaya kemitraan sebagai pelaksanaan tanggung jawab sosial perusahaan, diharapkan dapat menberikan dampak signifikan terhadap peningkatan kesejahteraan rakyat.

${ }^{1}$ Untuk selanjutnya Undang-Undang Nomor 19 Tahun 2003 tentang Badan Usaha Milik Negara akan disingkat UUBUMN.

${ }^{2}$ Dalam Penjelasan UUBUMN, selain menjalankan peran tersebut, BUMN memiliki peran sebagai pelopor dan/atau perintis dalam sektor-sektor usaha yang belum diminati usaha swasta, memiliki peran strategis BUMN sebagai pelaksana pelayanan publik, peran BUMN sebagai penyeimbang kekuatan-kekuatan swasta besar, dan peran BUMN untuk turut membantu pengembangan usaha kecil/koperasi. Lebih lanjut, BUMN juga memiliki peran sebagai salah satu sumber penerimaan negara yang signifikan dalam bentuk berbagai jenis pajak, dividen, dan hasil privatisasi. 
Akan tetapi, dalam pelaksanaannya, masyarakat Indonesia masih jauh dari sejahtera. Peran BUMN dalam meningkatkan kesejahteraan masyarakat belum optimal. Salah satu contohnya adalah BUMN yang bergerak di bidang industri pertanian khususnya pupuk. Sampai saat ini, kondisi perpupukan di Indonesia memiliki berbagai masalah yang serius. Padahal, pupuk merupakan faktor produksi yang sangat penting yang menyumbang 20 persen terhadap keberhasilan peningkatan produksi pertanian. ${ }^{3}$

Dalam berbagai aspek, peranan BUMN belum terlaksana secara ideal seperti apa yang diamanatkan Pasal 33 UUD 1945. Padahal, pengurusan dan pengawasan BUMN telah dilaksanakan berdasarkan prinsip-prinsip GCG yang merujuk pada Peraturan Menteri BUMN Nomor: PER-01/MBU/2011 tentang Penerapan Tata Kelola Perusahaan yang Baik (Good Corporate Governance/GCG) pada BUMN. ${ }^{4}$

Pelaksanaan tanggung jawab sosial perusahaan BUMN sebagai salah satu wujud penerapan GCG juga masih jauh dari harapan. Padahal, peran BUMN melalui tanggung jawab sosial perusahaan, sejatinya mampu mewujudkan 3 (tiga) pilar utama pembangunan (triple tracks) yang telah dicanangkan pemerintah. Pilar tersebut yaitu: 1) pengurangan jumlah pengangguran (pro-job); 2) pengurangan jumlah penduduk miskin (pro-poor); dan 3) peningkatan pertumbuhan ekonomi (pro-growth). ${ }^{5}$

\section{Rumusan Masalah}

Berdasarkan uraian di atas, permasalahan yang akan dikaji adalah: pertama, bagaimanakah peranan BUMN dalam menghasilkan barang dan/atau jasa yang bermutu tinggi dengan harga yang terjangkau melalui pengurusan dan pengawasan BUMN berdasarkan prinsip-prinsip GCG? Kedua, bagaimanakah peranan BUMN untuk turut membantu pengembangan usaha kecil/koperasi melalui pelaksanaan Tanggung Jawab Sosial Perusahaan dalam rangka meningkatkan kesejahteraan masyarakat?

\footnotetext{
${ }^{3}$ Permasalahan Pupuk dan Langkah-langkah Penanganannya, http://www.setneg.go.id/index.php? option $=$ com content\&task $=$ view\&id $=3369 \&$ Itemid $=29,23$ Februari 2009.

${ }^{4}$ Untuk selanjutnya Peraturan Menteri BUMN Nomor: PER-01/MBU/2011 tentang Penerapan Tata Kelola Perusahaan yang Baik (good corporate governance/ GCG) pada BUMN akan disingkat Permen BUMN Tentang Penerapan GCG.

${ }^{5}$ Asdep Pembinaan Kemitraan dan Bina Lingkungan Kementrian BUMN, Kebijakan Kementerian BUMN tentang CSR, disampaikan pada Rakor "Penguatan Pengelolaan Peluang Kerja dan Peluang Usaha", Bandung, 14-15 November 2010.
} 


\section{Tujuan Penelitian}

Adapun tujuan penelitian ini adalah: pertama, untuk mengkaji peranan BUMN dalam menghasilkan barang dan/atau jasa yang bermutu tinggi dengan harga yang terjangkau melalui pengurusan dan pengawasan BUMN berdasarkan prinsip-prinsip GCG. Kedua, peranan BUMN untuk turut membantu pengembangan usaha kecil/ koperasi melalui pelaksanaan tanggung jawab sosial Perusahaan dalam rangka meningkatkan kesejahteraan masyarakat.

\section{Metode Penelitian}

Penelitian ini menggunakan metode pendekatan yuridis normatif, yang dilakukan dengan cara meneliti bahan pustaka yang merupakan data sekunder. Melalui metode ini, inventarisasi peraturan perundang-undangan mengawali kegiatan dari penelitian dan UUD 1945 menjadi landasan tertinggi. Lebih lanjut, dianalisis kesesuaiannya sebagai landasan hukum peranan BUMN dalam melaksanakan amanat Pasal 33 UUD 1945 dengan tujuan meningkatkan kesejahteraan rakyat dan peranan BUMN melalui pelaksanaan tanggung jawab sosial perusahaan.

Spesifikasi penelitian menggunakan deskriptif analitis. Penelitian merupakan penelitian bidang hukum, dengan tujuan untuk memperoleh pemahaman tentang peranan BUMN dalam melaksanakan amanat Pasal 33 UUD 1945 dan peranan BUMN melalui pelaksanaan tanggung jawab sosial perusahaan BUMN dalam kaitannya dengan peningkatan kesejahteraan rakyat.

Setelah data terkumpul, lalu dilakukan analisis data. Peneliti menganalisis data secara yuridis kualitatif, yaitu secara sistematis dan lengkap, untuk kemudian dikaji dalam bentuk deskripsi yang analitik tanpa mempergunakan rumus yang bersifat matematis. Berdasarkan analisis tersebut, kemudian akan dibuat simpulan-simpulan penerapan prinsip-prinsip GCG dari 7 BUMN industri pertanian dalam hal ini pupuk dan pelaksanaan tanggung jawab sosial perusahaan secara khusus atau secara deduktif. 


\section{Hasil Penelitian dan Pembahasan}

\section{Prinsip-Prinsip GCG dalam Pengurusan dan Pengawasan BUMN}

Istilah Corporate Governance untuk pertama kali diperkenalkan oleh Cadbury Committee pada 1992 dalam laporannya yang dikenal dengan Cadbury Report. Corporate Governance menurut Cadbury Report adalah... the system by which organisations are directed and controlled". Artinya, suatu sistem yang berfungsi untuk mengarahkan dan mengendalikan organisasi. ${ }^{6}$

Melalui konsep GCG, hubungan dan mekanisme kerja, pembagian tugas, kewenangan, dan tanggung jawab yang harmonis dapat terjalin, baik secara internal maupun eksternal. GCG menawarkan prinsip transparansi, akuntabilitas, responsibilitas, kewajaran dan independensi dalam pengelolaan perusahaan. Hal tersebut semata-mata ditujukan untuk meningkatkan nilai perusahaan demi kepentingan pemegang saham (shareholders) dan pihak yang berkepentingan (stakeholders). ${ }^{7}$

Artinya, melalui GCG perusahaan dapat meningkatkan kinerja dan nilai perusahaan karena tujuan pencapaiannya tidak hanya mengakomodasi kepentingan shareholders, melainkan juga kepentingan stakeholders. Dengan demikian, kesinambungan perusahaan secara jangka panjang dapat terwujud. Hal ini disebabkan karena peluang terjadinya dampak negatif dari aktivitas perusahaan dapat diminimalisir.

Penjelasan UU BUMN menyatakan, BUMN perlu menumbuhkan budaya korporasi dan profesionalisme antara lain melalui pembenahan pengurusan dan pengawasannya. Pengurusan dan pengawasan BUMN harus dilakukan berdasarkan prinsip-prinsip tata-kelola perusahaan yang baik/ GCG.

${ }^{6}$ Dalam I Nyoman Tjager,et al., Corporate Governance: Tantangan dan Kesempatan bagi Komunitas Bisnis Indonesia, Prenhallindo, Jakarta, 2003, hlm. 26. Definisi lainnya adalah "A set of rules that define the relationship between shareholders, managers, creditors, the government, employees and other internal and external stakeholders in respect to their rights and responsibilities". Artinya, seperangkat aturan yang merumuskan hubungan antara para pemegang saham, manajer, kreditor, pemerintah, karyawan dan pihak-pihak yang berkepentingan lainnya baik internal maupun eksternal sehubungan dengan hak-hak dan tanggung jawab mereka

7 Stakeholders adalah orang atau instansi yang berkepentingan dengan suatu bisnis atau perusahaan. R. Edward Freeman menjelaskan stakeholders sebagai individu-individu dan kelompok-kelompok yang dipengaruhi oleh tercapainya tujuan-tujuan tersebut. Menurut K. Bertens, stakeholders tersebut adalah para manajer yang memimpin perusahaan, para karyawan, para pemasok, para konsumen, masyarakat di sekitar pabrik atau lokasi perusahaan (masyarakat lokal), masyarakat luas, pemerintah, lingkungan hidup, dan sebagainya. Dalam K. Bertens, Pengantar Etika Bisnis, Karnisius, Yogyakarta, 2000, hlm. 163. 
Kewajiban melakukan pengurusan dan pengawasan perusahaan berdasarkan prinsip-prinsip GCG tertuang dalam Pasal 5 ayat (3) dan Pasal 6 ayat (3) UUBUMN. Direksi dan Komisaris/ Dewan Pengawas harus mematuhi anggaran dasar BUMN dan peraturan perundang-undangan serta wajib melaksanakan prinsip-prinsip profesionalisme, efisiensi, transparansi, kemandirian, akuntabilitas, pertanggungjawaban, serta kewajaran.

Panduan bagi perusahaan dalam membangun, melaksanakan dan mengkomunikasikan praktek GCG kepada pemangku kepentingan terdapat dalam Pedoman GCG Indonesia. Pedoman umum ini disusun oleh Komisi Nasional Kebijakan Governance (KNKG) 2006 sebagai penyempurnaan Pedoman yang telah diterbitkan 2001.

GCG adalah prinsip-prinsip yang mendasari suatu proses dan mekanisme pengelolaan perusahaan berlandaskan peraturan perundang-undangan dan etika berusaha. ${ }^{8}$ Dari rumusan tersebut tersimpul bahwa proses dan mekanisme pengelolaan perusahaan, baik swasta maupun BUMN dilandasi oleh prinsip-prinsip yang berlandaskan pada peraturan perundang-undangan dan etika berusaha. Pengurusan dan pengawasan BUMN merujuk pada prinsip-prinsip GCG yang menurut Pasal 3 Permen BUMN tentang Penerapan GCG adalah transparansi, akuntabilitas, pertanggungjawaban, kemandirian, dan kewajaran. ${ }^{9}$

Salah satu perwujudan penerapan GCG pada BUMN ditandai dengan terbentuknya komposisi Komisaris Independen. Pasal 13 Permen BUMN tentang Penerapan GCG menyatakan, bahwa dalam komposisi Dewan Komisaris/Dewan Pengawas, paling sedikit 20\% (dua puluh persen) merupakan anggota Dewan Komisaris/Dewan Pengawas Independen yang ditetapkan dalam keputusan pengangkatannya. ${ }^{10}$ Organ

\footnotetext{
${ }^{8}$ Pasal 1 angka 1 Permen BUMN Tentang Penerapan GCG.

9 Transparansi (transparency), yaitu keterbukaan dalam melaksanakan proses pengambilan keputusan dan keterbukaan dalam mengungkapkan informasi material dan relevan mengenai perusahaan; Akuntabilitas (accountability), yaitu kejelasan fungsi, pelaksanaan dan pertanggungjawaban Organ sehingga pengelolaan perusahaan terlaksana secara efektif; Pertanggungjawaban (responsibility), yaitu kesesuaian di dalam pengelolaan perusahaan terhadap peraturan perundang-undangan dan prinsip-prinsip korporasi yang sehat; Kemandirian (independency), yaitu keadaan di mana perusahaan dikelola secara profesional tanpa benturan kepentingan dan pengaruh/tekanan dari pihak manapun yang tidak sesuai dengan peraturan perundang-undangan dan prinsip-prinsip korporasi yang sehat; dan Kewajaran (fairness), yaitu keadilan dan kesetaraan di dalam memenuhi hak-hak Pemangku Kepentingan (stakeholders) yang timbul berdasarkan perjanjian dan peraturan perundang-undangan.

${ }^{10}$ Menurut Antonius Alijoyo dan Subarto Zaini, Komisaris Independen adalah anggota Komisaris yang berasal dari luar perusahaan (tidak memiliki hubungan afiliasi dengan perusahaan) yang dipilih secara transparan dan independen, memiliki integritas dan kompetensi yang memadai, bebas dari pengaruh yang berhubungan dengan kepentingan pribadi atau pihak lain, serta dapat bertindak secara objektif dan independen dengan berpedoman pada prinsip-prinsip GCG. Antonius Alijoyo dan Subarto Zaini, Komisaris Independen: Penggerak Praktik GCG di Perusahaan, Indeks, Jakarta, 2004, hlm. 54-55.
} 
pendukung Dewan Komisaris/ Dewan Pengawas salah satunya adalah Komite Audit. ${ }^{11}$

Wujud penerapan GCG pada BUMN juga ditandai dengan penyusunan Indikator Pencapaian Kinerja (Key Performance Indicators) oleh Dewan Komisaris/Dewan Pengawas. Seperti yang tercantum dalam Pasal 15 Permen BUMN Tentang Penerapan GCG, RUPS wajib menetapkan Indikator Pencapaian Kinerja (Key Performance Indicators) Dewan Komisaris/Dewan Pengawas berdasarkan usulan dari Dewan Komisaris/Dewan Pengawas yang bersangkutan. Indikator Pencapaian Kinerja merupakan ukuran penilaian atas keberhasilan pelaksanaan tugas dan tanggung jawab pengawasan dan pemberian nasihat oleh Dewan Komisaris/Dewan Pengawas sesuai dengan ketentuan peraturan perundang-undangan dan/atau anggaran dasar.

\section{Tanggung Jawab Sosial Perusahaan pada BUMN}

Mukti Fajar dalam disertasinya menyatakan, bahwa telah terjadi pergeseran kewajiban moral dan etika perusahaan dari tanggung jawab sosial perusahaan, menjadi kewajiban hukum. Apabila hukum tidak mencerminkan nilai moral, maka akan mengakibatkan suatu aturan hukum kehilangan substansinya menciptakan keadilan. ${ }^{12}$

Pada saat pelaksanaan tanggung jawab sosial perusahaan di Indonesia bersifat voluntary, artinya belum diatur dalam Undang-Undang Nomor 40 Tahun 2007 tentang Perseroan Terbatas (UU PT), perusahaan di Indonesia terutama PT, melaksanakan tanggung jawab sosial perusahan secara beragam dan sangat tergantung dari kesadaran dan tanggung jawab sosial PT terhadap masyarakat dan kelestarian lingkungan terutama di sekitar perusahaan.

Berbeda dengan BUMN, dalam Pasal 88 UU BUMN dijelaskan, bahwa BUMN dapat menyisihkan sebagian laba bersihnya untuk keperluan pembinaan usaha kecil/koperasi serta pembinaan masyarakat sekitar BUMN. Peraturan Menteri Negara BUMN Nomor: PER-05/MBU/2007 Tentang Program Kemitraan Badan Usaha Milik Negara dengan Usaha Kecil dan Program Bina Lingkungan

\footnotetext{
${ }^{11}$ Peraturan menteri yang secara khusus mengatur tentang Komite Audit adalah Permen Nomor: PER-10/ MBU/2012 Tentang Organ Pendukung Dewan Komisaris/ dewan Pengawas BUMN. Dalam Pasal 12 Permen tersebut dijelaskan bahwa Komite Audit bekerja secara kolektif dalam melaksanakan tugasnya membentuk Dewan Komisaris/ Dewan Pengawas. Komite Audit bersifat mandiri baik dalam pelaksanaan tugasnya maupun dalam pelaporan dan bertanggung jawab langsung kepada Dewan Komisaris/Dewan Pengawas.

${ }_{12}$ Mukti Fajar ND., Tanggung jawab Sosial Perusahaan di Indonesia: Studi tentang Penerapan Ketentuan CSR pada Perusahaan Multinasional, Swasta Nasional, dan BUMN di Indonesia, Pustaka Pelajar, Yogyakarta, 2010, hlm. 124-134.
} 
$(\mathrm{PKBL})^{13}$ merupakan peraturan pelaksana secara teknis ketentuan Pasal 88 UU BUMN. Permen BUMN Tentang PKBL tersebut mewajibkan BUMN menyisihkan dan menggunakan laba perusahaan untuk membina usaha kecil/ koperasi dan masyarakat sekitar BUMN melalui program PKBL. Dengan demikian, sebelum dikeluarkannya UU PT yang mewajibkan PT melaksanakan tanggung jawab sosial perusahaan, BUMN melaksanakan tanggung jawab sosial perusahaannya melalui PKBL.

Secara konsep, PKBL yang dilaksanakan BUMN tidak jauh berbeda dengan best practices tanggung jawab sosial perusahaan yang dilakukan oleh perusahaan swasta sehingga dapat dikatakan bahwa PKBL merupakan praktik tanggung jawab sosial perusahaan yang dilakukan BUMN. ${ }^{14}$ Sejalan dengan pendapat tersebut, Mukti Fajar berpendapat bahwa bentuk-bentuk pelaksanaan tanggung jawab sosial perusahaan yang dilakukan BUMN dalam hal ini dikenal dengan istilah PKBL sebagai pelaksanaan tanggung jawab sosial perusahaan. ${ }^{15}$

Seperti yang terdapat dalam Pasal 1 Angka 6 Permen BUMN Tentang PKBL, Program Kemitraan BUMN dengan Usaha Kecil, adalah program untuk meningkatkan kemampuan usaha kecil agar menjadi tangguh dan mandiri melalui pemanfaatan dana dari bagian laba BUMN. ${ }^{16}$

\section{Peranan BUMN dalam Menghasilkan Barang dan/atau Jasa yang Bermutu Tinggi dengan Harga yang Terjangkau melalui Pengurusan dan Pengawasan BUMN berdasarkan Prinsip-Prinsip GCG agar dapat Meningkatkan Kesejahteraan Masyarakat.}

Pasal 33 UUD 1945 menjadi dasar konstitusional pelaku usaha dalam perekonomian nasional termasuk BUMN menjadikan kesejahteraan masyarakat

${ }^{13}$ Peraturan Menteri Negara BUMN Nomor: PER-05/MBU/2007 telah diubah oleh Peraturan Menteri Negara Badan Usaha Milik Negara Nomor PER-07/MBU/2013 Tentang Perubahan Ketiga Atas Peraturan Menteri Negara Badan Usaha Milik Negara Nomor PER-05/MBU/2007 Tentang Program Kemitraan Badan Usaha Milik Negara Dengan Usaha Kecil Dan Program Bina Lingkungan Sebagaimana Telah Diubah Dengan Peraturan Menteri Badan Usaha Milik Negara Nomor PER-20/MBU/2012 Tanggal 27 Desember 2012 Dan Peraturan Menteri Badan Usaha Milik Negara Nomor PER-05/MBU/2013 Tanggal 1 Mei 2013. Permen tersebut untuk selanjutnya disebut Permen BUMN tentang PKBL.

${ }^{14}$ Asdep Pembinaan Kemitraan dan Bina Lingkungan Kementrian BUMN, Kebijakan Kementrian BUMN tentang CSR, disampaikan pada Rakor "Penguatan Pengelolaan Peluang Kerja dan Peluang Usaha”, Bandung, 14-15 November 2010.

${ }^{15}$ Mukti Fajar, Op. Cit., hlm. 278-280.

${ }^{16}$ Usaha kecil yang dapat menjalin kemitraan dengan BUMN memiliki kriteria tertentu dari segi kepemilikan modal, kemandiriannya dengan usaha lain, bentuk usaha, potensi dan prospeknya, pengalaman menjalankan usaha, dan akses terhadap perbankan. Mengenai kriteria terakhir, usaha kecil yang dapat berperan serta dalam program kemitraan adalah usaha kecil yang belum memenuhi persyaratan perbankan (non bankable). 
sebagai tujuan akhirnya. Oleh karena itu, Pasal 33 UUD 1945 sebagai landasan eksistensi dan peranan BUMN mengamanatkan tujuan untuk sebesar-besarnya kemakmuran rakyat kepada BUMN dalam menjalankan pengelolaan cabang produksi yang penting bagi negara dan menguasai hajat hidup orang banyak. Upaya untuk mengoptimalkan peran BUMN salah satunya adalah profesionalisme dalam hal pengurusan dan pengawasan melalui penerapan prinsip-prinsip GCG.

Penerapan prinsip-prinsip GCG tersebut sangat penting dalam pengelolaan dan pengawasan BUMN. Pengalaman membuktikan bahwa keterpurukan ekonomi di berbagai negara termasuk Indonesia, antara lain disebabkan perusahaanperusahaan di negara tersebut tidak menerapkan prinsip-prinsip GCG secara konsisten.

Pada dasarnya, BUMN bidang industri pertanian khususya pupuk yaitu: 1) PT Pupuk Kujang; 2) PT. Pupuk Petrokimia Gresik; 3) PT. Pupuk Kaltim, 4) PT. Pupuk Iskandar Muda, 5) PT. Pupuk Sriwijaya, 6) PT. Mega Eltra, dan 7) PT. Rekayasa Industri yang tergabung dalam PT Pupuk Indonesia Holding Company (HC) melakukan pengurusan dan pengawasan perusahaannya berdasarkan prinsipprinsip GCG. Dalam Annual Report Tahun 2011, ke-7 BUMN pupuk yang tergabung dalam perusahaan kelompok dengan PT. Pupuk Indonesia HC sebagai perusahaan holding, telah menerapkan prinsip-prinsip GCG dalam pengurusan dan pengawasan perusahaan.

Idealnya, tujuan dari prinsip GCG berdasarkan Permen BUMN Tentang Penerapan GCG adalah agar nilai BUMN optimal sehingga dapat bersaing baik di tingkat nasional maupun internasional dan mencapai keberlanjutan usaha. Selain itu, melalui GCG pengelolaan BUMN dilakukan secara profesional, efisien, dan efektif serta terjamin kemandirian pengelolaan dari organ BUMN. Lebih lanjut, pengambilan keputusan dan tindakan Direksi BUMN dilandasi nilai moral yang tinggi dan kepatuhan pada peraturan perundang-undangan.

Setiap kebijakan Direksi dalam pengurusan perusahaan dan Komisaris dalam pengawasan perusahaan pada prakteknya telah menerapkan prinsip-prinsip GCG. Penerapan prinsip-prinsip GCG pada BUMN telah sesuai dengan Pasal 3 Permen BUMN Tentang Penerapan GCG, yaitu transparansi akuntabilitas, responsibilitas, kemandirian, dan kewajaran atau keadilan.

Ke-7 BUMN pupuk telah menerapkan prinsip keadilan dalam wujud jaminan perlakuan yang setara kepada para pemegang saham melalui mekanisme RUPS 
maupun RUPSLB. Pemegang saham dijamin hak-haknya tidak terlanggar. Perusahaan memenuhi kewajiban terkait dengan pemegang saham sesuai dengan ketentuan yang berlaku. Whistle Blowing System/WBS (Penanganan Pengaduan Karyawan dan Pihak Berkepentingan) merupakan salah satu perangkat pengendalian internal Perusahaan yang dirancang dan dijalankan untuk mengidentifikasi dan mendeteksi kemungkinan adanya kecurangan serta pelangggaran terhadap peraturan yang berlaku. Selain itu WBS merupakan saluran formal bagi stakeholders untuk menyampaikan pengaduan atau keluhan.

Prinsip transparansi, mengandung unsur keterbukaan yang harus diterapkan dalam setiap aspek di perusahaan yang berkaitan dengan kepentingan publik atau pemegang saham. Dalam Annual Report 2011, ke-7 BUMN pupuk telah menerapkan prinsip transparansi dalam pengelolaan perusahaannya melalui jaminan tersedianya informasi yang dapat diakses oleh stakeholder sesuai dengan kebutuhan dan kepentingannya. Pengelolaan website sebagai upaya pengungkapan informasi perusahaan sesuai dengan prinsip-prinsip dan parameter best practice penerapan GCG, termasuk didalamnya adalah informasi mengenai Tata Cara Pengelolaan Perusahaan, Kode Etik Perusahaan, Statement of Corporate Intent (SCI), dan Annual Report yang disusun sesuai dengan kaidah GCG.

Untuk dapat mengelola risiko usaha dengan baik, ke-7 BUMN pupuk menyusun kebijakan manajemen risiko, yang harus dilaksanakan di setiap unit kerja. Setiap pimpinan unit kerja bertanggung jawab atas terlaksananya kebijakan manajemen risiko di unit kerjanya masing-masing, guna mewujudkan terciptanya suatu sistem pengelolaan risiko yang akurat dan komprehensif untuk mendukung pencapaian tujuan perusahaan secara keseluruhan.

Prinsip akuntabilitas diwujudkan antara lain dengan menyiapkan Laporan Keuangan (Financial Statement) pada waktu yang tepat dengan cara yang tepat; mengembangkan Komite Audit dan risiko untuk mendukung fungsi pengawasan oleh Dewan Komisaris; mengembangkan dan merumuskan kembali peran dan fungsi Internal Audit sebagai mitra bisnis strategis berdasarkan best practices.

Melalui Annual Report 2011, Ke-7 BUMN pupuk pada umumnya telah menerapkan prinsip akuntabilitas dalam pengelolaan perusahaannya. Laporan keuangan secara berkala disusun oleh perusahaan dan dapat diakses oleh masyarakat secara transparan. Selain itu, ke-7 BUMN pupuk telah membentuk Komisaris Independen yang bertindak secara objektif dan independen dalam 
mengawasi kinerja direksi. Dewan Komisaris dibantu oleh Komite Audit yang bertugas membantu Komisaris dalam memastikan efektifitas sistem pengendalian intern dan tugas ekstern dan internal audit. Komite Audit juga bertugas memastikan telah terdapat prosedur evaluasi yang memuaskan terhadap segala informasi yang dikeluarkan perusahaan.

Ke-7 BUMN pupuk telah menyusun indikator pencapaian kerja (Key Performance Indicators) sebagai ukuran penilaian atas keberhasilan pelaksanaan tanggung jawab pengawasan dan pemberian nasehat. Direksi bertanggung jawab dalam memenuhi Key Performance Indicator yang jelas, lengkap, dan berimbang, baik dari aspek keuangan maupun non-keuangan untuk menentukan pencapaian misi dan tujuan Perusahaan sesuai dengan Statement Corporate Intent (SCI).

Dalam Annual Report 2011 dari ke-7 BUMN pupuk tergambar bahwa Direksi diwajibkan menerapkan prinsip-prinsip GCG dalam pengurusan perusahaan. Tugas dan kewenangan Direksi telah ditetapkan dalam panduan tata kelola perusahaan, panduan perilaku (code of conduct), dan board of manual. Menjadi kewajiban Direksi dalam menetapkan sistem pengendalian internal untuk mengamankan investasi dan aset perusahaan. Namun, dari ke-7 BUMN pupuk tersebut, PT. Pupuk Sriwidjaja dan PT. Mega Eltra yang mengungkapkan secara rinci dan lengkap penerapan GCG pada perusahaannya dari mulai perwujudan prinsip transparansi sampai dengan prinsip responsibilitas.

PT. Pupuk Indonesia Holding Company memiliki peran strategis untuk mendukung ketahanan pangan nasional melalui penyediaan kebutuhan pupuk urea, NPK, dan pupuk organik. Tidak dapat dipungkiri bahwa ke-7 BUMN pupuk yang tergabung dalam perusahaan kelompok dengan PT. Pupuk Indonesia Holding Company sebagai perusahaan induk, mengemban tugas strategis sebagai amanat Pasal 33 UUD 1945. Ke-7 BUMN pupuk harus mampu berperan melalui pengelolaan cabang produksi dalam hal ini pupuk untuk sebesar-besarnya kemakmuran rakyat. Dengan demikian, melalui BUMN yang pengelolaan perusahaannya harus dilakukan secara profesional, efisien dan efektif dengan mengusung prinsip pure business, tujuan akhir yang hendak dicapai adalah tetap kemakmuran rakyat.

Akan tetapi, dalam kenyataannya ketersediaan pupuk yang terjangkau sesuai dengan daya beli petani masih sulit. Data World Bank, 2008a; 2008b ${ }^{17}$ menunjukan, kebijakan penyediaan pupuk dengan harga murah melalui pemberian subsidi yang

\footnotetext{
${ }^{17}$ https://export.writer.zoho.com/public/adeputrajoni/i/fullpage, diakses 12 Mei 2013.
} 
terus meningkat setiap tahun, menyebabkan semakin tidak efisiensinya penggunaan pupuk oleh petani dan meningkatkan ketidaktepatan sasaran subsidi pupuk. Kelangkaan pasokan dan melonjaknya harga serta penyaluran pupuk bersubsidi yang kurang tepat sasaran terus terjadi dan berulang setiap tahun erat kaitannya dengan aspek teknis (data base petani dan kepemilikan lahan yang kurang akurat), aspek regulasi dan aspek manajemen.

Persoalan mendasar adalah kesenjangan antara kebutuhan akan produk pertanian input dengan pasokan pupuk itu sendiri yang disebabkan oleh perbedaan harga pupuk yang ditetapkan pemerintah dengan harga riil di lapangan. Selain itu, sasaran masyarakat petani penerima subsidi pada kebanyakan kasus tidak tepat sasaran.

Peran produsen pengadaan dan penyaluran pupuk bersubsidi dalam menjalankan amanat Pasal 33 UUD 1945 pada dasarnya bertujuan untuk kemakmuran rakyat. Oleh karena itu, sejatinya petani setidak-tidaknya mendapatkan manfaat dari pengadaan dan penyaluran pupuk bersubsidi yang diproduksi ke-7 BUMN industri pertanian khususnya pupuk.

Akan tetapi, sampai saat ini kondisi petani masih jauh dari sejahtera. Oleh karena itu, peran ke-7 BUMN industri pertanian dalam hal ini pupuk dalam pengadaan dan penyaluran pupuk bersubsidi kepada petani belum optimal. Padahal, apabila dilihat dari laporan keuangan maupun laporan keberlanjutan perusahaan, pada dasarnya ke-7 BUMN industri pertanian terutama pupuk telah menerapkan prinsipprinsip GCG dalam pengurusan dan pengawasannya.

Dengan demikian, prinsip GCG yang sejatinya menjadi dasar pengelolaan/ pengurusan serta pengawasan BUMN seperti yang terdapat dalam penjelasan UU BUMN belum cukup untuk menjadi landasan peranan BUMN pupuk dalam menyediakan pupuk untuk sebesar-besarnya kemakmuran rakyat. Dibutuhkan adanya dukungan dari para stakeholders dan juga peraturan perundang-undangan agar peranan BUMN berjalan secara optimal mensejahterakan masyarakat. Peraturan perundang-undangan sejatinya mengatur secara harmonis mengenai prinsip-peinsip pengelolaan dan sumber kekayaan BUMN.

Bila merujuk pada penjelasan UU BUMN, BUMN khususnya persero harus dijalankan dengan konsep bisnis murni berdasarkan UU PT seperti layaknya Perseroan Terbatas yang dalam artikel ini akan ditulis perusahaan. ${ }^{18}$ Tujuan

${ }^{18}$ Ridwan Khairandy, "Karakter Hukum Perusahaan Perseroan dan Status Hukum Kekayaan yang Dimilikinya”, dalam Jurnal Hukum Ius Quia Iustum, Vol. 20, No. 1, Januari 2013, hlm. 96. Menurut Ridwan Khairandi, Persero 
perusahaan yang berorientasi pada keuntungan menjadikan pengelolaan perusahaan dilakukan secara profesional. Artinya, sepanjang pengambilan kebijakan perusahaan telah memenuhi rambu-rambu aturan, maka Direksi perusahaan tidak dapat dipersalahkan apabila ternyata akibat kebijakan tersebut, perusahaan mengalami kerugian. Dalam Pasal 104 UU PT, sepanjang Direksi dapat membuktikan bahwa kerugian bukan akibat kesalahannya, maka Direksi dapat terlepas dari penuntutan untuk melaksanakan pertanggungjawaban secara tidak terbatas.

Dalam kenyataannya, hal tersebut tidak dapat sepenuhnya dilaksanakan BUMN. Pengambilan kebijakan BUMN yang seharusnya berorientasi bisnis murni, akan tetapi tidak dapat dilakukan karena seringkali berbenturan dengan peraturanperaturan yang mengakibatkan peran BUMN menghasilkan barang dan jasa yang bermutu tinggi tidak dapat optimal dilakukan. Apabila BUMN rugi akibat pengambilan kebijakan yang sebetulnya telah berlandaskan prinsip-prinsip perusahaan termasuk di dalamnya prinsip GCG, BUMN tetap dapat dikenai ketentuan merugikan keuangan negara.

BUMN sebagai pelaku usaha yang menjalankan bisnis murni seperti layaknya perusahaan swasta, yang pengambilan kebijakannya seharusnya juga murni untuk kepentingan bisnis, seringkali berbenturan dengan peraturan perundang-undangan yang membatasinya. Beberapa peraturan perundang-undangan terkait BUMN dalam hal ini UU BUMN, UU PT, UU Nomor 17 Tahun 2003 tentang Keuangan Negara. ${ }^{19}$ UU Nomor 1 Tahun 2004 tentang Perbendaharaan Negara, ${ }^{20}$ UU No. 49 Prp Tahun 1960 tentang Panitia Urusan Piutang Negara (PUPN), ${ }^{21}$ dan UU Nomor 20 Tahun 2001 tentang Perubahan Atas UU Nomor 31 Tahun 1999 tentang Pemberantasan Tindak Pidana Korupsi ${ }^{22}$ tidak singkron mengatur mengenai prinsip-prinsip pengelolaan BUMN dan kategori kekayaan BUMN sebagai sumber keuangan negara.

identik dengan perseroan terbatas, dan merupakan badan hukum privat yang tunduk kepada hukum privat. Oleh karena itu, kekayaan keseluruhan yang ada pada Persero adalah milik Persero itu sendiri, bukan milik negara.

${ }^{19}$ Undang-Undang Nomor 17 Tahun 2003 tentang Keuangan Negara untuk selanjutnya akan disingkat UU Keuangan Negara. Menurut Arifin P. Soeria Atmadja, menyatakan keuangan negara mengandung arti sempit dan luas. Pengertian keuangan negara dalam arti yang luas adalah keuangan negara yang berasal dari APBN, Anggaran Pendapatan Belanja Daerah (APBD), dan keuangan yang berasal dari Unit Usaha Negara atau perusahaan-perusahaan milik negara. Keuangan negara dalam arti sempit mengandung makna keuangan negara yang berasal dari APBN saja. Arifin P. Soeria Atmadja, Mekanisme Pertanggungjawaban Keuangan Negara: Suatu Tinjauan Yuridis, Gramedia, Jakarta, 1986, hlm. 51-54.

${ }^{20}$ Undang-Undang Nomor 1 Tahun 2004 tentang Perbendaharaan Negara untuk selanjutnya akan disingkat UU Perbendaharaan Negara.

${ }^{21}$ Undang-Undang No. 49 Prp Tahun 1960 tentang Panitia Urusan Piutang Negara (PUPN) untuk selanjutnya akan disingkat UU PUPN.

${ }^{22}$ Undang-Undang Nomor 20 Tahun 2001 tentang Perubahan Atas Undang-Undang Nomor 31 Tahun 1999 
Menurut UU BUMN, kekayaan negara yang dipisahkan untuk menjadi modal BUMN terutama Persero, merupakan kekayaan BUMN yang harus dikelola berdasarkan prinsip-prinsip tata kelola perusahaan yang baik berdasarkan UU PT. Kekayaan negara yang dipisahkan bukan lagi menjadi kekayaan negara yang tunduk pada ketentuan tentang Keuangan Negara yaitu UU Keuangan Negara. Sementara itu, menurut Pasal 2 huruf g UU Keuangan Negara, kekayaan yang berasal dari BUMN menjadi salah satu sumber keuangan negara.

Oleh karena itu, bagi Direksi BUMN yang menyebabkan kerugian dalam pengambilan kebijakan perusahaan dapat dijadikan tersangka tindak pidana korupsi berdasarkan UU Tindak Pidana Korupsi. Hai ini disebabkan karena kekayaan BUMN adalah sumber keuangan negara menurut UU Keuangan Negara, sehingga apabila ada unsur kerugian negara maka akan berhadapan dengan UU Tindak Pidana Korupsi. Padahal, tujuan PT adalah pure business dan kerugian merupakan suatu hal yang wajar dalam sebuah bisnis perusahaan.

Menurut hemat penulis, terlepas dari adanya ketidaksingkronan peraturan perundang-undangan, sebagai salah satu pelaku usaha dalam perekonomian nasional yang mengemban amanat Pasal 33 UUD 1945 dengan kesejahteraan rakyat sebagai sasaran tujuannya, seharusnya BUMN dari awal menyadari perannya untuk menghasilkan barang dan atau jasa yang berkualitas dengan harga yang terjangkau. Pengelolaan BUMN berdasarkan prinsip-prinsip tata kelola yang baik tetap memiliki tujuan sebesar-besarnya kemakmuran dan kesejahteraan rakyat.

Oleh karena itu, seharusnya tidak perlu muncul alasan adanya ketidaksingkronan undang-undang untuk agar BUMN dapat berperan menghasilkan barang dan/atau jasa yang bermutu tinggi dengan harga yang kompetitif. BUMN tidak lagi harus mempermasalahkan dikotomi peraturan perundang-undangan terkait BUMN antara lain UU BUMN, UU PT, UU Keuangan Negara, UU Perbendaharaan Negara, UU PUPN dan UU Tindak Pidana Korupsi. Dalam menjalankan perannya, tidak lagi harus dipermasalahkan apakah pengelolaan BUMN tunduk pada prinsip tata kelola perusahaan yang baik atau prinsip keuangan negara. Termasuk pula tidak lagi harus ada alasan ketidakoptimalan menjalankan peran BUMN sesuai amanat Pasal 33 UUD 1945 karena adanya kekhawatiran kesalahan pengambilan kebijakan yang berimplikasi terhadap kerugian keuangan negara dan perekonomian negara berdasarkan UU Tindak Pidana Korupsi. 
Mengenai pengambilan kebijakan direksi BUMN yang pure business dan nyatanya berdampak pada kerugian BUMN serta implikasinya terhadap berlakunya ketentuan UU Tindak Pidana Korupsi memang telah ada contoh kasus riil nya. Seperti hasil wawancara yang dilakukan dengan Bagian Hukum Kementerian BUMN Bapak Anas, ${ }^{23}$ BUMN yang bergerak di bidang perkebunan karet dan sawit di Lampung, Direksinya ditetapkan telah merugikan keuangan negara yang melanggar UU Tindak Pidana Korupsi. Padahal, pengambilan kebijakan yang dilakukan Direksi adalah pure business yang dilandasi profesionalisme. Kerugian muncul karena dipengaruhi oleh faktor eksternal yaitu kondisi harga karet dan sawit ketika itu yang secara dramatis melambung tinggi.

Contoh kasus di atas tidak dapat digeneralisasikan untuk dikenai UU Tindak Pidana Korupsi terhadap setiap kebijakan Direksi terutama yang mengakibatkan kerugian bagi BUMN. Tetap saja akan dilihat kasus per kasus terhadap setiap kebijakan Direksi tersebut.

Dengan demikian tersimpul, BUMN belum berperan secara optimal dalam menghasilkan pupuk yang bermutu tinggi dengan harga yang terjangkau oleh masyarakat. Kalaupun ada pupuk yang berkualitas tinggi yang diproduksi BUMN pupuk, tetapi seringkali sulit dijangkau oleh petani. Walaupun ke-7 BUMN pupuk telah memproduksi jenis pupuk bersubsidi yang dibutuhkan petani sebagai faktor produksi pemenuhan kebutuhan masa tanam, tetapi pada kenyataannya petani mengalami kesulitan untuk mendapatkan jenis pupuk tersebut. Permasalahan distribusi di lapangan bukan merupakan hal yang sederhana. Ketersediaan dan kelancaran sarana prasarana fasilitas umum menjadi salah satu faktor penghambat tersalurkannya jenis pupuk bersubsidi sampai ke tangan petani. Hal tersebut menjadi pekerjaan rumah yang tidak pernah terselesaikan oleh BUMN. Padahal, pengurusan dan pengawasan BUMN telah dilaksanakan berdasarkan prinsip GCG.

Artinya, BUMN dalam melaksanakan amanat Pasal 33 UUD 1945 belum berperan optimal meningkatkan kesejahteraan masyarakat. Peraturan perundangundangan yang tidak singkron secara horizontal seperti yang dijelaskan di atas menjadi salah satu penyebab belum optimalnya peranan BUMN.

${ }^{23}$ Hasil wawancara yang dilakukan dengan Bagian Hukum kementerian BUMN pada 04 April 2013. 


\section{Peranan BUMN melalui Pelaksanaan Tanggung Jawab Sosial Perusahaan dalam Rangka Meningkatkan Kesejahteraan Masyarakat berdasarkan Hukum Ekonomi Nasional.}

Konsep dasar tanggung jawab sosial perusahaan adalah adanya kontribusi terhadap stakeholders selain untuk kepentingan perusahaan semata-mata. Tujuan akhir aktivitas bisnis perusahaan tidak hanya sekedar profit oriented, melainkan perhatian dan kontribusi nyata terhadap peningkatan kualitas hidup masyarakat sekitar khususnya dan masyarakat umum serta lingkungan hidup pada umumnya. Telah banyak bukti adanya peningkatan nilai perusahaan secara signifikan karena pelaksanaan tanggung jawab sosial perusahaan yang dilakukan berwujud nyata, sesuai dengan bisnis intinya dan berkesinambungan.

Direksi harus memastikan agar BUMN melaksanakan tanggung jawab sosialnya serta memperhatikan kepentingan dari berbagai pemangku kepentingan sesuai dengan ketentuan peraturan perundang-undangan. Salah satu peran BUMN dalam melaksanakan amanat Pasal 33 UUD 1945 adalah turut membantu pengembangan usaha kecil/koperasi yang terdapat dalam Pasal 88 UU BUMN. Permen BUMN Tentang PKBL secara teknis mengatur tentang pembinaan usaha kecil/ koperasi dan masyarakat sekitar BUMN melalui program PKBL.

Pasca dikeluarkannya UU PT, tanggung jawab sosial perusahaan wajib dilakukan perusahaan dengan kriteria tertentu. Pasal 74 UU PT mewajibkan perusahaan yang menjalankan kegiatan usahanya di bidang sumber daya alam dan/ atau berkaitan dengan sumber daya alam melaksanakan tanggung jawab sosial dan lingkungan. Artinya, BUMN dengan kriteria tersebut juga wajib melakukan tanggung jawab sosial perusahaan seperti yang diatur dalam UU PT. Dengan demikian, pasca dikeluarkannya UU PT, BUMN yang mengelola dan memanfaatkan SDA serta BUMN yang kegiatan usahanya berdampak pada fungsi kemampuan sumber daya alam, wajib melaksanakan CSR sekaligus PKBL.

Berkaitan dengan pelaksanaan PKBL, tujuan yang hendak dicapai BUMN lebih luas dari pelaksanaan tanggung jawab sosial yang dilakukan PT pada umumnya. Tujuan tersebut yakni terciptanya tiga pilar pembangunan yaitu tersedianya lapangan pekerjaan (pro-job), dapat mengentaskan kemiskinan (pro-poor), dan mendorong pertumbuhan ekonomi (pro-growth). Berdasarkan wawancara dengan Kabid. PKBL I kementerian BUMN, Edward Nurdin, terdapat satu lagi pilar yang hendak 
dicapai yaitu terciptanya kelestarian fungsi lingkungan hidup (pro-environment). Walaupun dalam praktek, pelaksanaan tanggung jawab sosial perusahaan melalui PKBL BUMN tidak seideal konsepnya. Sasaran yang hendak dicapai dari PKBL BUMN pada prakteknya paling tidak masyarakat petani dapat makan sehari tiga kali, dari yang biasa makan hanya satu kali sehari. ${ }^{24}$

Melihat kenyataan tersebut, seolah-olah BUMN menyusun target pelaksanaan tanggung jawab sosial perusahaan melalui PKBL BUMN yang jauh panggang dari pada api. Target terwujudnya empat pilar pembangunan dari pelaksanaan tanggung jawab sosial perusahaan melalui PKBL BUMN sulit untuk diimplementasikan.

Disadari betul bahwa BUMN mengemban amanat yang cukup besar dalam mencapai tujuan akhir kemakmuran dan kesejahteraan rakyat. Jangankan dalam pelaksanaan tanggung jawab sosial perusahaan, dalam menjalankan peranannya menghasilkan barang dan/atau jasa dengan kualitas yang baik dan terjangkau masyarakat saja masih belum optimal. A palagi melalui pelaksanaan tanggung jawab sosial perusahaan yang merupakan bentuk dari peran BUMN untuk turut membantu pengembangan usaha kecil/koperasi.

Oleh karena itu, tujuan yang hendak dicapai dalam pelaksanaan tanggung jawab sosial perusahaan paling tidak dapat membantu mengembangkan usaha kecil/ koperasi agar tercapai kemandirian usaha. Melalui program kemitraan yang terwujud dalam bentuk pinjaman yang diberikan kepada usaha kecil/koperasi diharapkan setidaknya akan membuka akses permodalan. Selama ini akses permodalan usaha kecil/koperasi tidak seterbuka pelaku usaha menengah ke atas.

Seperti yang terdapat dalam Permen BUMN Tentang PKBL, pelaksanaan tanggung jawab sosial perusahaan diharapkan dapat menumbuhkan kemandirian dan ketangguhan usaha kecil/koperasi. Melalui pinjaman yang diberikan, keberlangsungan usaha kecil/koperasi dapat terwujud.

Satu hal yang perlu diperhatikan, kata kunci keberhasilan pelaksanaan tanggung jawab sosial perusahaan dalam hal ini PKBL BUMN ada pada keterlibatan, partisipasi dan peran serta masyarakat dalam rencana pengambilan kebijakan perusahaan terkait pelaksanaan PKBL tersebut. ${ }^{25}$ Perusahaan wajib menyediakan media yang didalamnya menampung aspirasi masyarakat di mana perusahaan

\footnotetext{
${ }^{24}$ Hasil wawancara dengan Kabid. PKBL I kementerian BUMN, Edward Nurdin, 04 April 2013.

${ }^{25}$ Yeti Sumiyati, Kepatutan dan Kewajaran sebagai Ukuran pelaksanaan tanggung Jawab Sosial dan Lingkungan Perseroan Terbatas, artikel dalam buku "Dinamika Hukum dari Sentripetal ke Sentrifugal: Perjuangan Memelihara Hukum Bersukma Keadilan di Tanah Negeri, FH Unisba, Bandung, 2013.
} 
tersebut berdomisili, untuk bersama-sama menentukan bentuk dan model pelaksanaan tanggung jawab sosial perusahaan. Upaya ini perlu dilakukan agar pelaksanaan tanggung jawab sosial perusahaan dalam hal ini PKBL BUMN betulbetul tepat sasaran dan memberikan manfaat bagi masyarakat terutama dalam bentuk kegiatan yang dapat mendorong kemandirian ekonominya. Selain itu, pelaksanaan tanggung jawab sosial perusahaan BUMN juga harus memberi ruang kepada masyarakat untuk ikut mengawal agar tepat sasaran memberikan rasa keadilan bagi masyarakat.

Merujuk pada pelaksanaan tanggung jawab sosial perusahaan ke-7 BUMN pupuk, terlihat jelas ada kontribusi signifikan terhadap peningkatan kualitas kehidupan masyarakat sekitar perusahaan. Ada beberapa kegiatan tanggung jawab sosial perusahaan dalam hal ini PKBL BUMN sebagai bentuk pengungkapan sosial yang telah dilakukan.

Seperti yang dikemukakan Eko Suyono, pada dasarnya pengungkapan pelaksanaan tanggung jawab sosial perusahaan dalam Annual Report maupun secara spesifik dalam sustainability report setidaknya membagi 6 (enam) kategori pengungkapan sosial. Kategori tersebut adalah pengungkapan sosial terkait dengan lingkungan, kepedulian terhadap tenaga kerja, energi, community, produk, dan dampak ekonomi terhadap masyarakat. ${ }^{26}$ Dalam paktiknya, selain perusahaan yang melakukan pengungkapan sosial secara sunggung-sungguh dan menganggap penting aktivitas tersebut, ada juga yang sebatas memenuhi syarat bahwa perusahaan tersebut sudah memenuhi kepedulian sosial, seperti yang telah dilakukan perusahaan lain. ${ }^{27}$

Secara umum, ke-7 BUMN pupuk membagi kegiatan kepedulian kepada masayarakat pada bidang pemberdayaan sosial masyarakat, pemberdayaan ekonomi masyarakat dan perlindungan lingkungan hidup. Secara riil kegiatan kemitraan dan bina lingkungan terdiri dari pemberian pinjaman kepada usaha kecil, bantuan bencana alam, pendidikan dan/atau pelatihan, peningkatan kesehatan, penyelenggaraan sarana dan prasarana umum, penyelenggaraan sarana ibadah dan pelestarian alam.

Sesuai dengan Permen PKBL Tentang PKBL BUMN, ke-7 BUMN pupuk membuka akses permodalan melalui pemberian pinjaman kepada pelaku usaha

\footnotetext{
${ }^{26}$ Eko Suyono, Corporate Social Responsibility di Indonesia: antara Harapan dan Realitas, Unpad Press, Bandung, 2010, hlm. 129-130.

${ }^{27}$ Ibid.
} 
kecil/koperasi di sekitar BUMN tersebut beroperasi. Selain itu juga diberikan pelatihan mulai dari perencanaan produksi, kegiatan produksi sampai pemasaran kepada pengusaha yang menjadi mitra binaan. Pembayaran pinjaman tersebut dilakukan dengan syarat bagi hasil antara mitra binaan dan BUMN. Pembagian hasil mulai dari 10\% hingga 50\% sesuai dengan kesepakatan awal.

Tersimpul dari Annual Report dan Sustainability Report Tahun 2011 ke-7 BUMN pupuk, bahwa belum adanya format yang seragam dalam pengungkapan sosialnya. PT. Pertokimia Gresik dan PT. Pupuk Kaltim melakukan pengungkapan sosial secara sunggung-sungguh dan menganggap penting aktivitas tersebut. Hal ini dapat terlihat dari rinci dan jelasnya rencana, pelaksanaan dan evaluasi Program kemitraan dan Bina Lingkungan. Pelaksanaan tanggung jawab sosial perusahaan melalui PKBL dari PT. Pertokimia Gresik dan PT. Pupuk Kaltim berjalan secara berkesinambungan. Hal ini dapat dilihat dari lancarnya pengembalian pinjaman dari mitra binaan, sehingga memungkinkan disalurkannya pinjaman kepada mitra binaan baru secara berkelanjutan.

Pencapaian ini sesuai dengan salah satu prinsip tanggung jawab sosial perusahaan menurut Crowter dan Aras yaitu sustainability atau berkelanjutan. ${ }^{28}$ Pemberian pinjaman sebagai bentuk Program Kemitraan yang disisihkan dari laba BUMN dapat secara berkesinambungan diberikan kepada mitra binaan dengan jaminan pengembalian pinjaman tersebut. Hal ini disebabkan karena pemberian pinjaman kepada mitra binaan yang berskala usaha kecil disertai pemberian pelatihan usaha dari mulai perencanaan produksi, kegiatan produksi, sampai dengan pemasarannya. Kenyataan ini cukup menggembirakan walaupun belum cukup menjadikan pelaku usaha kecil khususnya petani secara ekonomi mandiri. Menurut Agus dari Balai Besar Padi, usaha pertanian baru akan mendatangkan keuntungan (break even point) bagi petani, apabila petani mengelola areal pertanian di atas 0,7 Ha. ${ }^{29}$

Artinya, pelaksanaan tanggung jawab sosial perusahaan melalui PKBL BUMN yang efektif sekalipun sulit untuk mencapai empat pilar pembangunan ekonomi yaitu mengurangi pengangguran, mengentaskan kemiskinan dan meningkatkan pertumbuhan ekonomi serta perlindungan terhadap lingkungan hidup. Pelaksanaan

\footnotetext{
${ }^{28}$ David Crowther \& Guler Aras, Corporate Social Responsibility, Ventus Publishing ApS, 2008, hlm. 19-21.

${ }^{29}$ Hasil wawancara dengan manajer Umum PT Padi Energi Nusantara (PEN), Rusyad Nurdin, pada 04 April 2013.
} 
Program Kemitraan melalui pemberian pinjaman modal bagi usaha kecil/koperasi pertanian yang efektif, setidak-tidaknya dapat menumbuhkan kemandirian usaha tani. Petani dapat berkarya atas prakarsanya sendiri dalam hal permodalan untuk kebutuhan masa tanam.

Dengan demikian, merujuk pada pelaksanaan tanggung jawab sosial perusahaan dalam hal ini PKBL 7 BUMN pupuk, peran BUMN untuk turut membantu pengembangan usaha kecil/koperasi melalui pelaksanaan tanggung jawab sosial perusahaan atau PKBL BUMN telah terlihat nyata wujudnya dalam meningkatkan kualitas kehidupan petani. Peran BUMN dalam pelaksanaan tanggung jawab sosial perusahaan telah mampu mendorong kemandirian ekonomi rakyat apabila Program Kemitraan melalui pemberian pinjaman kepada mitra binaan yang berskala usaha kecil/koperasi apabila disertai pemberian pelatihan usaha dari mulai perencanaan produksi, kegiatan produksi, sampai dengan pemasarannya.

Akan tetapi paling tidak, melalui pelaksanaan tanggung jawab sosial perusahaan, BUMN telah berupaya berkontribusi memberikan pendidikan kepada masyarakat untuk berkarya di atas prakarsanya sendiri. Melalui Program kemitraan dalam bentuk pinjaman kepada petani setidaknya memberikan solusi terhadap masalah akses permodalan petani yang non-bankable.

\section{Penutup}

BUMN dalam menjalankan peranannya menghasilkan barang dan/atau jasa dalam hal ini pupuk yang bermutu tinggi dan terjangkau oleh masyarakat belum optimal, walaupun pengurusan dan pengawasan ke-7 BUMN pupuk telah berlandaskan prinsip-prinsip GCG. Alasan ketidakoptimalan peranan BUMN tersebut karena adanya ketidaksingkronan peraturan perundang-undangan secara horizontal terkait prinsip pengelolaan dan sumber kekayaan BUMN yang berdampak pada optimalisasi pengambilan kebijakan Direksi BUMN.

Peranan BUMN untuk turut membantu pengembangan usaha kecil/koperasi petani melalui pelaksanaan tanggung jawab sosial perusahaan berdasarkan Permen BUMN

Tentang PKBL baru akan optimal mendorong kemandirian ekonomi petani apabila pelaksanaannya berjalan secara berkesinambungan. Dari mulai perencanaan, pelaksanaan kegiatan sampai pada pelaporan kegiatan tanggung jawab sosial 
perusahaan dalam hal ini PKBL BUMN, BUMN harus melibatkan partisipasi masyarakat petani. Pelaksanaan PKBL juga tidak terbatas pada pemberian pinjaman, tetapi sampai pada pemberian pelatihan mulai dari perencanaan produksi, kegiatan produksi sampai pemasaran kepada pelaku usaha kecil/koperasi pertanian.

\section{Daftar Pustaka}

Alijoyo, Antonius dan Subarto Zaini, Komisaris Independen: Penggerak Praktik GCG di Perusahaan, Indeks, Jakarta, 2004.

Bertens, K., Pengantar Etika Bisnis, Karnisius, Yogyakarta, 2000.

Crowther, David \& Guler Aras, Corporate Social responsibility, Ventus Publishing ApS, 2008.

Fajar ND., Mukti, Tanggung jawab Sosial Perusahaan di Indonesia: Studi tentang Penerapan Ketentuan CSR pada Perusahaan Multinasional, Swasta Nasional, dan BUMN di Indonesia, Pustaka Pelajar, Yogyakarta, 2010.

Khairandy, Ridwan, "Karakter Hukum Perusahaan Perseroan dan Status Hukum Kekayaan yang Dimilikinya”, Jurnal Hukum Ius Quia Iustum, Vol. 20, No. 1, Januari 2013.

Nyoman Tjager, I,et al., Corporate Governance: Tantangan dan Kesempatan bagi Komunitas Bisnis Indonesia, Prenhallindo, Jakarta, 2003.

P. Soeria Atmadja, Arifin, Mekanisme Pertanggungjawaban Keuangan Negara: Suatu Tinjauan Yuridis, Gramedia, Jakarta, 1986.

Sumiyati, Yeti, Kepatutan dan Kewajaran sebagai Ukuran pelaksanaan tanggung Jawab Sosial dan Lingkungan Perseroan Terbatas, artikel dalam buku "Dinamika Hukum dari Sentripetal ke Sentrifugal: Perjuangan Memelihara Hukum Bersukma Keadilan di Tanah Negeri, FH Unisba, Bandung, 2013.

Suyono, Eko, Corporate Social Responsibility di Indonesia: antara Harapan dan Realitas, Unpad Press, Bandung, 2010.

Undang-Undang Nomor 1 Tahun 2004 tentang Perbendaharaan Negara

Undang-Undang Nomor 17 Tahun 2003 Tentang Keuangan Negara

Undang-Undang Nomor 19 Tahun 2003 tentang BUMN

Undang-Undang Nomor 20 Tahun 2001 tentang Perubahan Atas Undang-Undang Nomor 31 Tahun 1999 Tentang Pemberantasan Tindak Pidana Korupsi untuk selanjutnya akan disingkat UU Tindak Pidana Korupsi.

Undang-UndangNomor 40 Tahun 2007 Tentang Perseroan Terbatas

Permen Nomor: PER-10/MBU/2012 Tentang Organ Pendukung Dewan Komisaris/ dewan Pengawas BUMN. 
Permen BUMN Nomor : PER-01 /MBU/2011 Tentang Penerapan Prinsip-Prinsip Tata Kelola Perusahaan yang Baik/ GCG pada BUMN

Peraturan Menteri Negara BUMN Nomor PER-05/MBU/2007 Tentang Program Kemitraan Badan Usaha Milik Negara dengan Usaha Kecil dan Program Bina Lingkungan (PKBL)

Pedoman Umum GCG Indonesia, KNKG, 2006.

Hasil wawancara yang dilakukan dengan Bagian Hukum kementerian BUMN pada tanggal 04 April 2013.

Hasil wawancara yang dilakukan dengan Kepala Bagian PKBL I Kementerian BUMN pada tanggal 04 April 2013.

Hasil wawancara dengan manajer Umum PT Padi Energi Nusantara (PEN), Rusyad Nurdin, pada 04 April 2013.

Asdep Pembinaan Kemitraan dan Bina Lingkungan Kementrian BUMN, Kebijakan Kementrian BUMN tentang CSR, disampaikan pada Rakor "Penguatan Pengelolaan Peluang Kerja dan Peluang Usaha”, Bandung, 14-15 November 2010 .

Permasalahan Pupuk dan Langkah-langkah Penanganannya, http:// www.setneg.go.id/index.php?option $=$ com_content\&task=view\&id= 3369\&Itemid=29, 23 Februari 2009.

https://export.writer.zoho.com/public/adeputrajoni/i/fullpage, diakses 12 Mei 2013. 